\title{
Pemetaan Status pH Tanah dan C-Organik Tanah Sawah Tadah Hujan di Kecamatan Panai Tengah Kabupaten Labuhanbatu
}

\section{Mapping of Soil pH and C-Organic Status of Rainfed Rice Fields in Panai Tengah District, Labuhanbatu Regency}

\author{
Fitra Syawal Harahap*1), Dedi Kurniawan²), Rini Susanti3) \\ 1)Department of Agrotechnology, Faculty of Sains and Technology, Universitas Labuhanbatu, Labuhanbatu \\ ${ }^{2)}$ Program Study of Agrotechnology, Faculty of Agriculture and Animal Husbandry, Universitas Tjut Nyak Dien, Medan \\ ${ }^{3)}$ Department of Agrotechnology, Faculty of Agriculture, Universitas Muhammadiyah Sumatera Utara, Medan \\ *Corresponding author: fitrasyawalharahap@gmail.com
}

Received: February 11, 2021; Accepted: March 26, 2021; Published: April 1, 2021

\begin{abstract}
The production center for lowland rice in Labuhanbatu Regency in the last three years, precisely in Panai Tengah District, North Sumatra Province, has decreased production since 2018. One of the causes is a decrease in production because the nutrient content in the soil has decreased and added by fertilizer application by farmers. Lowland rice is still common due to limited data on land resources. This study aims to evaluate the land through the identification of classes, distribution and status of soil $\mathrm{pH}$ and $\mathrm{C}$-Organic nutrients as well as organic matter in agricultural land in Central Panai District, and to determine the level of soil damage in each Land Mapping Unit. This research was carried out in Central Panai District with elevation. place 11 meters above sea level. Soil analysis was carried out in the integrated science laboratory of the Faculty of Science and Technology, Labuhanbatu University from January 2021 to March 2021, while the method in this study was a semi-detailed grid survey with the density of observation of 1 sample per 250 meters. Soil pH measurements used the $\mathrm{pH}-\mathrm{H}_{2} \mathrm{O}$ and $\mathrm{C}$-organic methods of soil using the Walkley and Black method. Furthermore, the results of the analysis of nutrient rainfed lowland soils are interpreted into a nutrient status map. The results showed that the $\mathrm{pH}$ content of rainfed lowland soil in Panai Tengah District, Labuhanbatu Regency was classified as very acidic and slightly acidic, while based on the soil nutrient status, namely C-organic and organic matter in the low category, so as to increase the productivity of rainfed lowland soil with soil organic matter content.up to $3 \%$ required organic fertilizer in the Central Panai District, Labuhanbatu Regency.
\end{abstract}

Key words: free grid survey; land mapping; nutrients

Cite this as: Harahap, F. S., Kurniawan, D. \& Susanti, R. (2021). Pemetaan status pH tanah dan c-organik tanah sawah tadah hujan di Kecamatan Panai Tengah Kabupaten Labuhanbatu. Agrosains : Jurnal Penelitian Agronomi, 23(1), 37-42. DOI: http://dx.doi.org/10.20961/agsjpa.v23i1.48479

\section{PENDAHULUAN}

Kecamatan Panai Tengah berada di kabupaten Labuhanbatu memiliki luas $\pm 483,74 \mathrm{~km}^{2}$ dengan luas lahan sawah menurut kecamatan dan jenis pengairan di Kabupaten Labuhanbatu (ha) sawah seluas $\pm 5980 \mathrm{Ha}$ desngan sawah tadah hujan 2167 ha serta pasang surut 3813 ha (BPS Kabupaten Labuhanbatu, 2016). Lahan sawah tadah hujan yang merupakan lahan sawah yang sumber airnya tergantung pada air hujan yang jatuh. Unutk Provinsi Sumatera Utara sendiri luas lahan sawah tadah hujan sekitar 149.547 ha (Triharto et al., 2014). Lahan sawah mempunyai sifat dan ciri tanah yang spesifik. Kondisi tergenang menyebabkan perbahan sifat kimia dan fisika tanah sehingga berakibat pada penurunan pertumbuhan atau produksi padi (Harahap et al., 2020). Menurut Harahap (2018), tanaman padi sawah yang dibudidayakan pada kondisi tanah tergenang akan mengakibatkan perubahan-perubahan sifat kimia tanah yang akan mempengaruhi pertumbuhan tanaman padi sementara menurut
Sahwan (2012), menyatakan bahwa lahan sawah yang terdegradasi umumnya berkaitan dengan rendahnya kandungan bahan organik tanah sehingga dengan demikian upaya untuk mengatasinya masalah degradasi yaitu dengan menambahkan bahan organik ke dalam tanah. Hasil penelitian Harahap et. al., (2020) menunjukkan bahwa lahan sawah terdegradasi salah satunya terindikasi karena bahan organik dan kalium rendah. Bahan organik memiliki peran penting dalam menentukan kemampuan tanah untuk mendukung tanaman, sehingga jika kadar bahan organik tanah menurun, kemampuan tanah dalam mendukung produktivitas tanaman juga menurun. Produktivitas suatu lahan sawah disamping ditentukan oleh status kesuburan tanahnya juga ditentukan oleh pengelolaannya seperti pemupukan, pengolahan lahan, sistem irigasi dan pengambilan bahan organiknya (Syawal et al., 2017).

Umumnya komoditi yang terdapat pada Kecamatan Panai Tengah adalah padi sawah tandah hujan 
sehingga pada umumnya rata-rata produksi di daerah ini adalah 3-4,5 ton/ha masih di bawah dari rata-rata produksi nasional yang dapat dicapai (8 ton/ha) (Chairuman, 2014). Berdasarkan wawancara dengan beberapa petani di beberapa Desa di Kecamatan Panai Tengah, salah satu penyebab rendahnya produksi padi sawah di daerah ini dikarenakan air pengairan yang masih bergantung kepada air hujan. Selain itu kurangnya pengetahuan petani tentang pemupukan yang tepat guna khususnya pada budidaya padi sawah juga menjadi penyebab rendahnya produksi yang dihasilkan. Menurut Baswarsiati \& Tafakresnanto (2019), dosis anjuran pemupukan untuk tanaman padi sawah adalah $250 \mathrm{~kg}$ Urea /ha, $100 \mathrm{~kg}$ SP-36 /ha dan $100 \mathrm{~kg} \mathrm{KCL} / \mathrm{ha}$. Dobermann \& Fairhust (2002) melaporkan bahwa pengolahan hara yang tidak berimbang akan menurunkan hasil padi hingga $40 \%$, dan apabila diikuti dengan pengolahan tanaman yang tidak baik maka kehilangan hasil padi dapat mencapai $60 \%$ dari potensi hasilnya.

Peta status $\mathrm{N}, \mathrm{P}$ dan $\mathrm{K}$ lahan sawah menggambarkan ketersediaan $\mathrm{N}, \mathrm{P}$, dan $\mathrm{K}$ dalam kondisi sangat rendah, rendah, sedang, tinggi dan sangat tinggi. Selain peta status $N, P$ dan $K$, kemasaman tanah atau ( $\mathrm{pH}$ Tanah), C-Organik tanah sawah juga penting untuk diketahui (Syawal, 2017). sedangkan menurut Yudichandra (2016) bahwa peta kemasaman tanah juga perlu diketahui karena $\mathrm{pH}$ tanah berhubungan dengan ketersediaan hara dalam tanah sehingga apabila status unsur hara $\mathrm{N}, \mathrm{P}, \mathrm{K}$ dan $\mathrm{pH}$ tanah telah diketahui, maka diharapkan dosis pemupukan setiap lahan dapat dilakukan sesuai dengan status hara pada lahan. hal tersebut juga dapat menghindari kerugian biaya akibat dari pemupukan yang berlebihan dan tidak sesuai dengan status hara pada lahan.

Tujuan penelitian ini adalah mengevaluasi lahan melalui identifikasi kelas, sebaran dan status hara $\mathrm{pH}$ tanah dan C-Organik serta bahan oganik di lahan pertanian di Kecamtan Panai Tengah, dan mengetahui tingkat degradasi tanah pada tiap Land Mapping Unit.

\section{BAHAN DAN METODE}

Penelitian ini dilaksanakan di Kecamatan Panai Tengah, Kabupaten Labuhanbatu dengan ketinggian kurang lebih 11 meter diatas permukaan laut pada titik koordinat $2^{\circ} 31^{\prime} 17.4 " \mathrm{~N}, 100^{\circ} 09^{\prime} 54.4 " \mathrm{E}$, sebagaimana disajikan pada Gambar 1. Analisa tanah dilakukan di Laboratorium IImu Terpadu Fakultas Sains Dan Teknologi Universitas Labuhanbatu, Labuhanbatu. Penelitian ini dilaksanakan pada bulan Januari-Maret 2021.

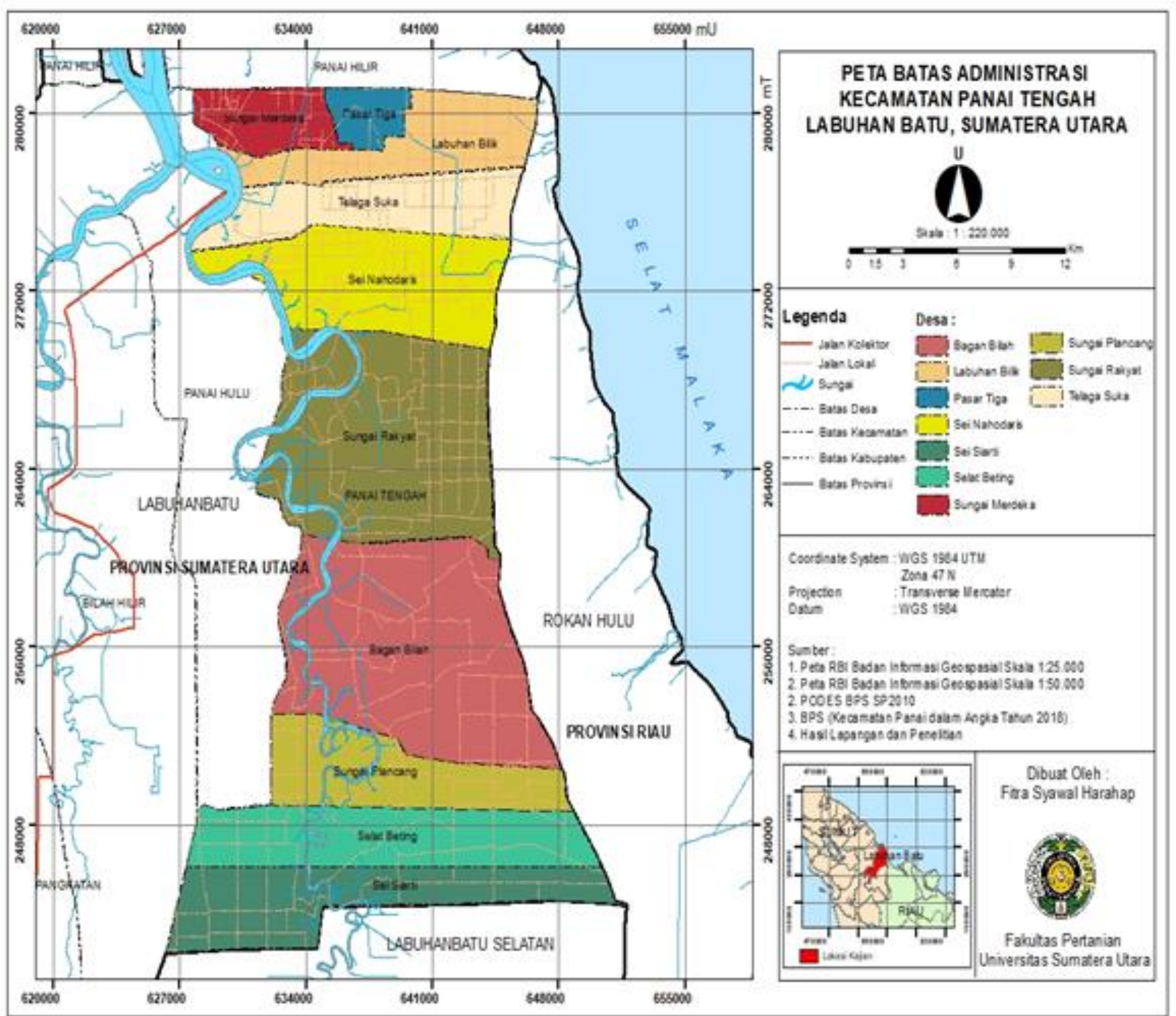

Gambar 1. Peta administrasi Kecamatan Panai Tengah Kabupaten Labuhanbatu 
Penelitian dimulai dengan pengambilan sampel tanah. Metode yang digunakan dalam penelitian ini adalah metode survey grid bebas tingkat survei semi detail (kerapatan pengamatan 1 sampel tiap 100 meter) Pelaksanaan pengambilan contoh tanah sebanyak 5 titik sampel dengan jarak 100 meter dilapangan yang menggunakan metode acak tersebar dengan luasan yang telah ditentukan dengan berpedoman pada peta dasar (Gambar 2). Pengambilan contoh tanah menggunakan cangkul/ bor tanah pada kedalaman 0 $20 \mathrm{~cm}$ sebanyak $\pm 1 \mathrm{~kg}$ tanah setiap pengambilan contoh tanah. Dari tiap pengambilan contoh tanah tersebut, dilakukan pencatatan hasil pembacaan koordinat pada GPS (Rauf \& Harahap, 2019).

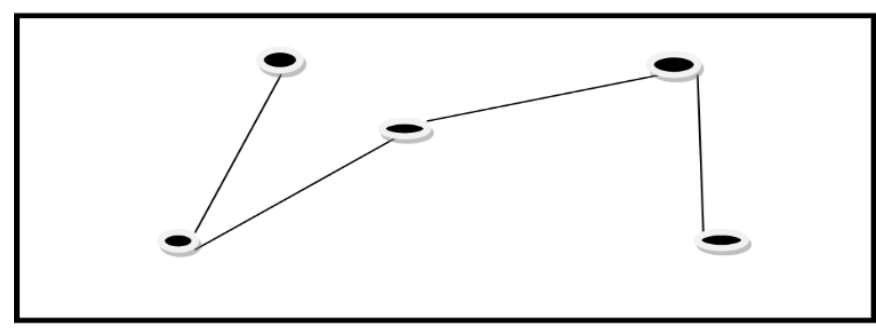

Gambar 2. Titik samping pengambilan sampel tanah di lokasi penelitian

Adapun parameter yang diamati meliputi pengukuran derajat kemasaman tanah ( $\mathrm{pH}$ tanah) metode $\mathrm{pH}$ meter, C-organik metode Walkley \& Black (\%), Bahan organik metode C-Organik x 1,724 sehingga data yang diperoleh, dianalisis dengan menggunakan analisis spasial menggunakan GIS (Geografic Information System). Output analisis spasial adalah cluster tingkat/kreteria $\mathrm{pH}$ tanah dan C-Organik Tanah dan bahan organik sehingga yang diperoleh dikelompokan berdasarkan kriteria penilaian sifat-sifat kimia tanah yang dibuat oleh Berdasarkan Kriteria Badan Penelitian dan Pengembangan Pertanian Kementerian Pertanian (2012) dan disajikan pada Tabel 1 berikut.

Tabel 1. Kriteria Penilaian Hasil Analisis Tanah

\begin{tabular}{|c|c|c|c|c|c|c|}
\hline $\begin{array}{l}\text { Sifat } \\
\text { Tanah }\end{array}$ & $\begin{array}{l}\text { Sangat } \\
\text { Rendah }\end{array}$ & Rendah & Sedang & Tinggi & $\begin{array}{r}\text { Sangat } \\
\text { Tinggi }\end{array}$ & \\
\hline C (\%) & $<1$ & $1-2$ & $2-3$ & $3-5$ & $>5$ & \\
\hline $\mathrm{pH}\left(\mathrm{H}_{2} \mathrm{O}\right)$ & $\begin{array}{c}\text { Sangat } \\
\text { Masam } \\
<4,5\end{array}$ & $\begin{array}{l}\text { Masam } \\
4,5-5,5\end{array}$ & $\begin{array}{c}\text { Agak } \\
\text { Masam } \\
5,6-6,5\end{array}$ & $\begin{array}{c}\text { Netral } \\
6,6-7,5\end{array}$ & $\begin{array}{c}\text { Agak } \\
\text { Alkalis } \\
7,6-8,5\end{array}$ & $\begin{array}{c}\text { Alkalis } \\
>8,5\end{array}$ \\
\hline
\end{tabular}

Sumber: Badan Penelitian dan Pengembangan Pertanian Kementerian Pertanian (2012)

\section{HASIL DAN PEMBAHASAN pH Tanah}

Hasil status hara $\mathrm{pH}$ tanah, di Kecamatan Panai Tengah Kabupaten Labuhanbatu berdasarkan hasil analisis kandungan unsur hara $\mathrm{pH}$ tanah dari sampel tanah sawah tadah hujan seperti pada Tabel 2. Kriteria hasil analisis kandungan $\mathrm{pH}$ tanah yang diamati berkisar antara agak masam, masam dan sangat masam. Kriteria ini berdasarkan Balai Penelitian Tanah Bogor (2009). Kelarutan Al dan Fe juga dipengaruhi oleh $\mathrm{pH}$ tanah. Pada $\mathrm{pH}$ asam, kelarutan $\mathrm{Al}$ dan $\mathrm{Fe}$ tinggi akibatnya pada $\mathrm{pH}$ sangat rendah pertumbuhan tanaman tidak normal karena suasana $\mathrm{pH}$ tidak sesuai, sehingga kelarutan beberapa unsur menurun dan adanya keracunan Al dan Fe (Rosmarkam dan Yuwono, 2002).
Tabel 2. Hasil analisis kandungan unsur hara $\mathrm{pH}$ tanah Sawah tadah hujan di Kecamatan Panai Tengah Kabupaten Labuhanbatu

\begin{tabular}{lcc}
\hline \multicolumn{1}{c}{ Desa } & Nilai & Kriteria \\
\hline Bagan Bilah & 4,67 & Masam \\
Labuhan Bilik & 5,23 & Masam \\
Pasar Tiga & 4,71 & Sangat Masam \\
Sei Merdeka & 4,83 & Sangat Masam \\
Sei Nahodaris & 5,87 & Agak Masam \\
Sei Plancang & 5,78 & Sangat Masam \\
Sei Rakyat & 4,55 & Masam \\
Sei Siarti & 5,81 & Agak Masam \\
Selat Beting & 5,75 & Agak Masam \\
Telaga Suka & 4,61 & Masam \\
\hline
\end{tabular}

Dari Hasil Tabel 2 menunjukkan status analisa $\mathrm{pH}$ tanah di Kecamatan Panai Tengah Kategori Masam di Desa Bagan Bilik, Labuhan Bilik, Sei Rakayat, Telaga Suka untuk kategori sangat masam Desa Pasar Tiga, Sei Merdeka, Sei Plancang sedangkan kategori agak masam Desa Sei Nahodaris, Sei Siarti, Selat Beting. Menurut Badan Penelitian dan Pengembangan Pertanian Kementerian Pertanian (2012), hal ini diakibatkan pada saat di lokasi kondisi sawah telah dipanen oleh para petani sehingga pengambilan sampel tanah dilakukan pada keadaan kering yang mengakibatkan proses oksidasi besi pada tanah sawah, sehingga $\mathrm{pH}$ tanah yang pada saat penggenangan mendekati netral menjadi masam kembali. Hal ini sesuai dengan keterangan Hardjowigeno et al., (2004) yang menyatakan pada proses pengeringan tanah sawah akan mengakibatkan oksidasi $\mathrm{Fe}^{2+}$ menjadi $\mathrm{Fe}^{3+}$ yang mengakibatkan $\mathrm{H}^{+}$pada tanah meningkat dan $\mathrm{pH}$ tanah menurun. beberapa faktor di antaranya akibat pengelahan lahan secara intesif, tercuci melalui penguapan ataupun leaching hal ini sesuai dengan pendapat Harahap et al., (2017), studi tingkat degradasi tanah sawah di desa serdang disebabkan oleh beberapa faktor di antaranya akibat pengelahan lahan secara intesif, tercuci melalui penguapan ataupun leaching, rendahnya kandungan, tidak digunakannya sisa tanaman sebelumnya.

\section{C-Organik Tanah (\%) dan Bahan Organik Tanah (\%)}

Hasil analisa status hara C-organik tanah (\%) serta bahan organik tanah (\%) di Kecamatan Panai Tengah Kabupaten Labuhanbatu berdasarkan hasil analisis kandungan unsur hara $\mathrm{pH}$ tanah dari sampel tanah sawah tadah hujan (Tabel 3). Hasil pemetaan kondisi kandungan C-organik dan Bahan organik di wilayah sawah di berada di Kecamatan Panai Tengah ini mengindikasikan bahwa tanah sawah di beberapa wilayah Desa Serdang telah terdegradasi dan membutuhkan penambahan bahan organik melalui penggunaam pupuk organik seperti misalnya pupuk kandang atau kompos sampah kota. Hal ini sesuai dengan pendapat Syawal et al., (2017) yang menyatakan bahwa tanah sawah di Kecamatan Beringin, Kabupaten Deli Serdang telah terdegradasi ditandai dengan bahan organik tanah tergolong sangat rendah sekitar 1 sampai $2,5 \%$ sehingga untuk meningkatkan produktivitas tanah sawah di Kecamatan Beringin dengan kandungan bahan organik tanah mencapai $3 \%$ diperlukan pupuk organik sebanyak 38,70 ton/ha sampai 77,40 ton/ha sehingga pemulihan kondisi tanah terdegradasi diharapkan dapat merehabilitasi 
kandungan tanah yang terdegradasi untuk mendukung pertumbuhan, perkembangan dan produksi tanaman padi yang optimal.

Tanah sawah di Kecamatan Panai Tengah memiliki status hara Sangat Rendah di desa Bagan Bilah, Labuhan bilik, Sei Siarti dan Selat Beting (Tabel 3). Kriteria rendah di Desa Pasar Tiga, Sei Merdeka, Seinahodaris, Selat Plancang, Sei Rakyat dan Telaga Suka berdasarkan kriteria Badan Penelitian dan Pengembangan Pertanian Kementerian Pertanian (2012). Status hara C-Organik Tanah (\%) dan bahan organik tanah (\%) pada lahan sawah tadah hujan di Kecamatan Panai Tengah Kabupaten Labuhanbatu termasuk rendah Hal ini sesuai dengan Mulyani \& Las (2008) yang menyebutkan bahwa $73 \%$ lahan pertanian Indonesia memiliki kandungan bahan organik yang rendah, $23 \%$ sedang, dan hanya $4 \%$ yang berstatus tinggi sementara kandungan bahan organik lahan pertanian di Indonesia secara umum termasuk rendah, disebabkan oleh masih rendahnya kesadaran petani untuk memberikan pupuk organik kedalam tanah.
Tabel 3. Hasil analisis kandungan unsur hara C-Organik Tanah (\%) serta Bahan organik tanah (\%) sawah tadah hujan di Kecamatan Panai Tengah Kabupaten Labuhanbatu

\begin{tabular}{|c|c|c|c|}
\hline \multirow[b]{2}{*}{ Desa } & \multicolumn{2}{|c|}{ Parameter } & \multirow[b]{2}{*}{ Kriteria } \\
\hline & $\begin{array}{c}\text { C-Organik } \\
(\%)\end{array}$ & $\begin{array}{c}\text { Bahan } \\
\text { Organik (\%) }\end{array}$ & \\
\hline Bagan Bilah & 0,81 & 1,20 & $\begin{array}{l}\text { Sangat } \\
\text { Rendah }\end{array}$ \\
\hline $\begin{array}{l}\text { Labuhan } \\
\text { Bilik }\end{array}$ & 0,75 & 0,46 & $\begin{array}{l}\text { Sangat } \\
\text { Rendah }\end{array}$ \\
\hline Pasar Tiga & 1,61 & 0,61 & Rendah \\
\hline $\begin{array}{l}\text { Sei } \\
\text { Merdeka }\end{array}$ & 1,23 & 1,35 & Rendah \\
\hline $\begin{array}{l}\text { Sei } \\
\text { Nahodaris }\end{array}$ & 1,71 & 0,95 & Rendah \\
\hline $\begin{array}{l}\text { Sei } \\
\text { Plancang }\end{array}$ & 1,83 & 0,85 & Rendah \\
\hline Sei Rakyat & 1,67 & 1,51 & Rendah \\
\hline Sei Siarti & 0,85 & 1,43 & $\begin{array}{l}\text { Sangat } \\
\text { Rendah }\end{array}$ \\
\hline Selat Beting & 0,71 & 1,61 & $\begin{array}{l}\text { Sangat } \\
\text { Rendah }\end{array}$ \\
\hline $\begin{array}{l}\text { Telaga } \\
\text { Suka }\end{array}$ & 1,55 & 1,73 & Rendah \\
\hline
\end{tabular}

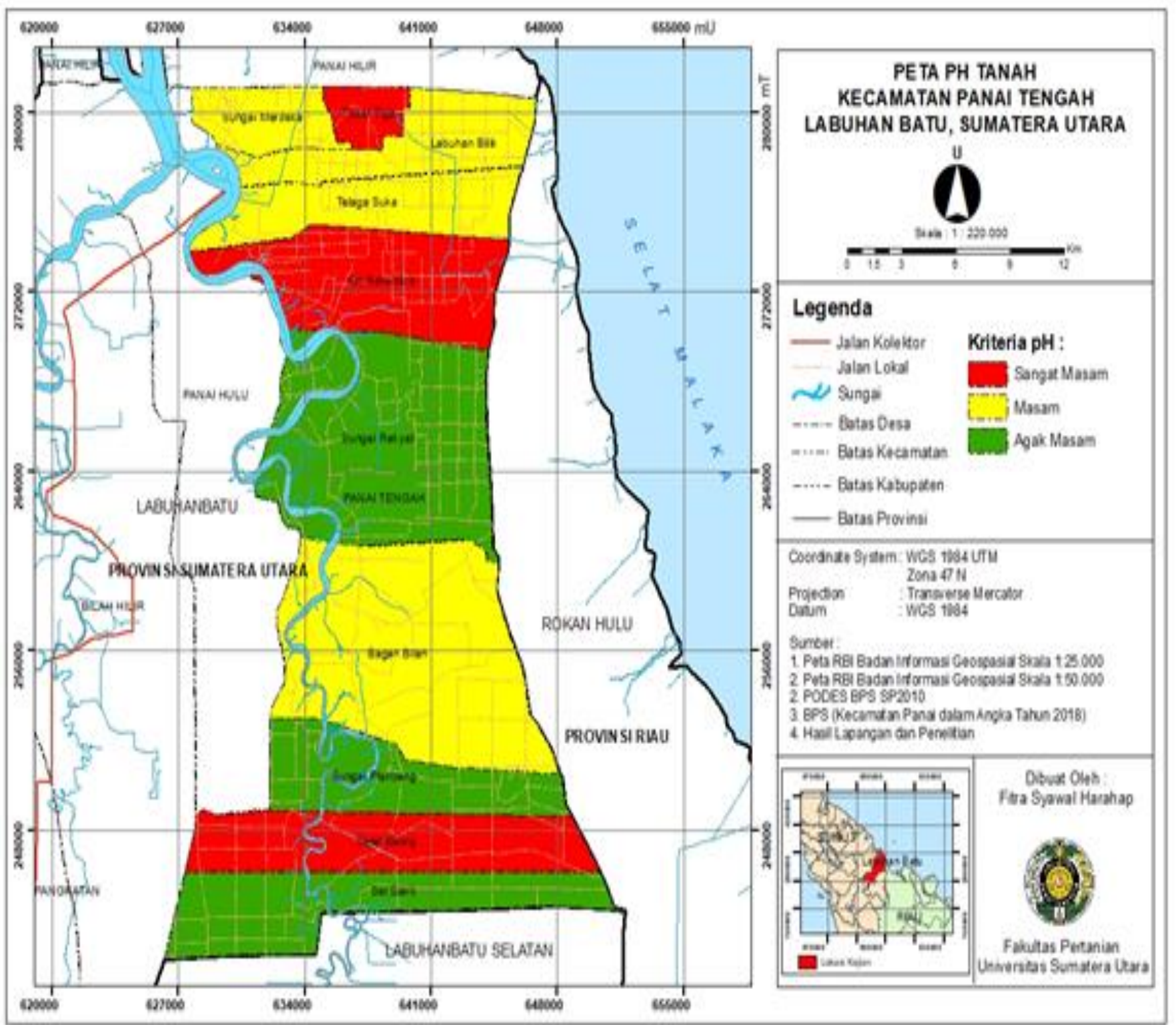

Gambar 3. Peta status hara pH Tanah di Kecamatan Panai Tengah Kabupaten Labuhanbatu 


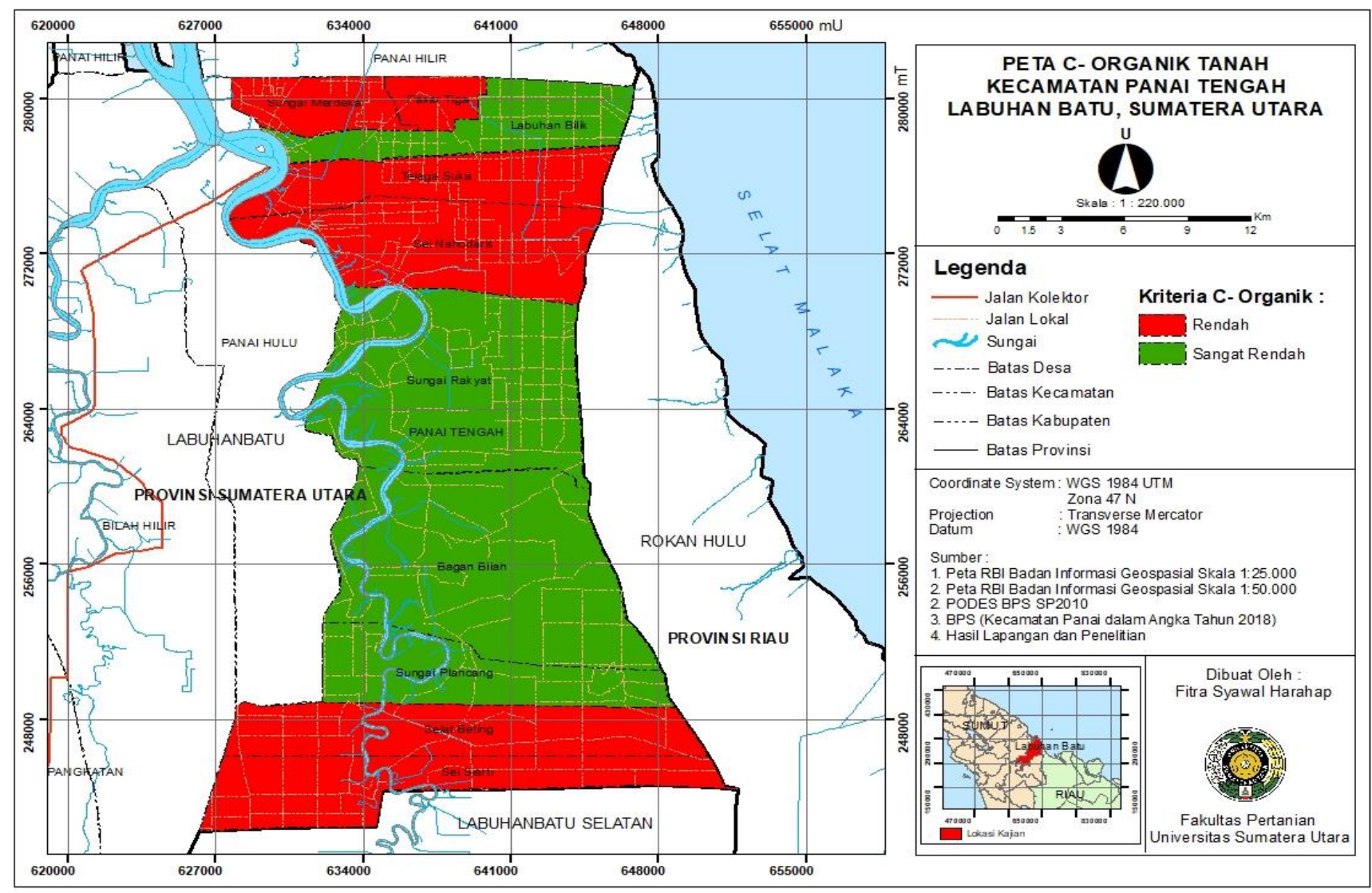

Gambar 4. Peta status hara C-Organik (\%) Tanah di Kecamatan Panai Tengah Kabupaten Labuhanbatu

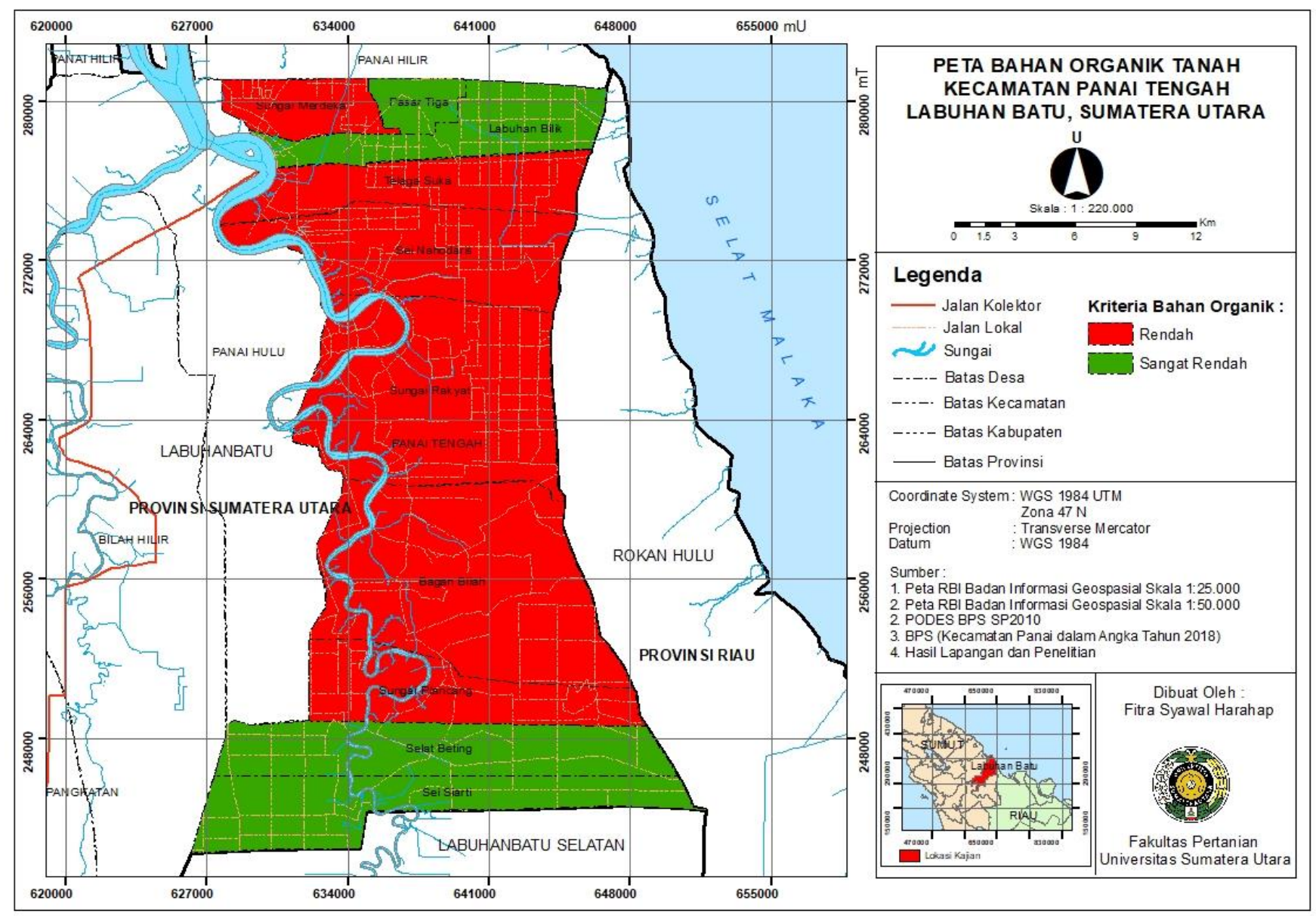

Gambar 5. Peta status hara Bahan Organik (\%) Tanah di Kecamatan Panai Tengah Kabupaten Labuhanbatu. 


\section{KESIMPULAN}

Berdasarkan status hara kandungan $\mathrm{pH}$ tanah sawah tadah hujan kategori sangat masam dan agak masam sedangkan untuk C-organik dan bahan organik kategori rendah sehingga untuk meningkatkan produktivitas tanah sawah tadah hujan dengan kandungan bahan organik tanah mencapai 3\% diperlukan pupuk organik di Kecamatan Panai Tengah Kabupaten Labuhanbatu.

\section{UCAPAN TERIMA KASIH}

Penulis mengucapkan terima kasih kepada Kementerian Riset dan Tekhnologi/Badan Riset dan Inovasi Nasional atas Dana Hibah Penelitian 2020 sehingga penelitian ini dapat berjalan lancar dan tepat waktu.

\section{DAFTAR PUSTAKA}

Agoesdy, R., Hanum, H., Rauf, A. and Harahap, F.S., (2019). Status hara fosfor dan kalium di lahan sawah di Kecamatan Tanjung Morawa Kabupaten Deli Serdang. Jurnal Tanah dan Sumberdaya Lahan, 6(2):1387-1390.

Badan Penelitian dan Pengembangan Pertanian Kementerian Pertanian. (2012). Petunjuk teknis analisis kimia tanah, tanaman, air dan pupuk. Edisi 2. Bogor. 204 hal.

Badan Pusat Statistik Kabupaten Labuhanbatu. (2016). https://labuhanbatukab.bps.go.id. Diakses pada tanggal 1 Januari 2021.

Baswarsiati, B. \& Tafakresnanto, C., (2019). Kajian penerapan good agricultural practices (GAP) bawang merah di Nganjuk Dan Probolinggo. Agrika, 13(2):147-161.

Chairuman, N. (2014). Kajian adaptasi beberapa varietas unggul baru padi sawah berbasis pendekatan pengelolaan tanaman terpadu di dataran tinggi Tapanuli Utara Provinsi Sumatera Utara. Jurnal Pertanian Tropik, 1(1): 47-54.

Dobermann, A. \& Fairhurst, T. H. (2002). Rice straw management. Better Crops International, 16(1): 7-11.

Harahap, F.S. (2018). Evaluasi status kesuburan NPK tanah sawah tadah hujan di Kecamatan Beringin Kabupaten Deli Serdang. Jurnal Agroplasma, 5(1): 30-34.

Harahap, F. S., Harahap, D. E. \& Harahap, P. (2020). Land characteristics and land evaluation for development on other use area rice fertilizer plants in District Salak Regency Pakpak Bharat. Ziraa'ah
Majalah Ilmiah Pertanian, 45(2): 195-204.

Harahap, F.S., Walida, H., Dalimunthe, B.A., Rauf, A., Sidabuke, S.H. and Hasibuan, R., 2020. The use of municipal solid waste composition in degradated waste soil effectiveness in aras kabu village, beringin subdistrict, Deli Serdang district. Agrinula, 3(1): 1927.

Mulyani, A. \& Las, I. (2008). Potensi sumber daya lahan dan optimalisasi pengembangan komoditas penghasil bioenergi di Indonesia. Jurnal litbang pertanian, 27(1), pp.31-41.

Rauf, A. \& Harahap, F.S. (2019). Optimalisasi lahan pertanian menggunakan agen biomassa. USU Press Medan. ISBN : 978-602-465-146-6.

Rosmarkam, A., \& Yuwono, D. N. (2002). Soil fertility science. Kanisius. Yogyakarta, Indonesia.

Sahwan, F. L. (2012). Potensi sampah kota sebagai bahan baku kompos untuk mendukung kebutuhan pupuk organik dalam rangka memperkuat kemandirian pangan. Jurnal Teknologi Lingkungan, 13(2):193-201.

Syawal, F., \& Rauf, A. (2017). Upaya rehabilitasi tanah sawah terdegradasi dengan menggunakan kompos sampah kota di Desa Serdang Kecamatan Beringin Kabupaten Deli Serdang. Jurnal Pertanian Tropik, 4(3), 183-189.

Syawal, F. (2017). Tingkat degradasi serta upaya rehabilitasi tanah sawah menggunakan kompos sampah kota di Kecamatan Beringin Kabupaten Deli Serdang. Magister Tesis, Universitas Sumatera Utara, Medan.

Syawal, F., Rauf, A., Rahmawaty, R. \& Hidayat, B. (2017). Pengaruh pemberian kompos sampah kota pada tanah terdegrdasi terhadap produktivitas tanaman padi sawah di Desa Serdang Kecamatan Beringin Kabupaten Deli Serdang. In Prosiding SEMDI-UNAYA (Seminar Nasional Multi Disiplin Ilmu UNAYA) 1(1): 41-51.

Triharto, S., Musa, L., \& Sitanggang, G. (2014). Survei dan pemetaan unsur hara $\mathrm{N}, \mathrm{P}, \mathrm{K}$, dan $\mathrm{pH}$ tanah pada lahan sawah tadah hujan di Desa Durian Kecamatan Pantai Labu. Jurnal Agroekoteknologi Universitas Sumatera Utara, 2(3), 100236.

Yudichandra, F. (2016). Pemetaan status unsur hara NPK dan $\mathrm{pH}$ tanah pada rencana lahan tanam kedelai sayur (edamame) di Desa Gugut, Kecamatan Rambipuji, Jember (Doctoral dissertation, Universitas Brawijaya). 